\title{
ASOCIACIONISMO RELIGIOSO. CAMBIOS Y PERMANENCIAS EN LA TRANSICIÓN DEL SIGLO XVIII AL SIGLO XIX. UN ESTUDIO DE CASO: LA COFRADÍA DEL SANTÍSIMO SACRAMENTO, SALTA, ARGENTINA, 1774-1880 \\ POR
}

\author{
VÍCTOR ENRIQUE QUINTEROS ${ }^{1}$ \\ Instituto de Investigaciones en Ciencias Sociales y Humanidades \\ Universidad Nacional de Salta-CONICET
}

RESUMEN

A través del presente artículo nos proponemos reconstruir la trayectoria histórica de la cofradía del Santísimo Sacramento, en la ciudad de Salta, en el periodo que se extiende desde 1774 a 1880, a fin de analizar los cambios y las permanencias que se observan en su composición social, organización interna, regulación jurisdiccional y prácticas devocionales, así como la vinculación de dichos factores con el proceso local de secularización.

PALABRAS CLAVE: cofradías; secularización; religiosidad.

\section{RELIGIOUS ASSOCIATION. CHANGES AND PERMANENCES IN THE TRANSITION FROM THE 18TH TO THE 19TH CENTURIES. A CASE STUDY: THE CONFRATERNITY OF BLESSED SACRAMENT, SALTA, ARGENTINA, 1774-1880}

\begin{abstract}
Through this article we propose to reconstruct the historical trajectory of the Confraternity of the Blessed Sacrament, in the city of Salta, in the period that extends from 1774 to 1880, in order to analyze the changes and the permanences that are observed in its social composition, internal organization, jurisdictional regulation and devotional practices, as well as the linkage of these factors with the local process of secularization.
\end{abstract}

KEY WORDS: confraternity; secularization; religiosity.

CÓMO CITAR ESTE ARTíCULO / CITATION: Quinteros, V. E. 2019. «Asociacionismo religioso. Cambios y permanencias en la transición del siglo XVIII al siglo XIX. Un estudio de caso: la cofradía del Santísimo Sacramento, Salta, Argentina, 1774-1880». Hispania Sacra 71, 143: 329-343. https://doi.org/10.3989/hs.2019.024

$\begin{array}{ll}\text { Recibido/Received } & 23-12-2016 \\ \text { Aceptado/Accepted } & 20-03-2017\end{array}$

\section{INTRODUCCIÓN}

En el transcurso de las últimas décadas, las cofradías y hermandades religiosas se convirtieron en objeto de estudio privilegiado de un número creciente de investigaciones históricas centradas en el análisis de la religiosidad y sociabilidad del Antiguo Régimen. A través del estudio de sus variadas composiciones sociales, sus sistemas de cargos y oficios, y sus recursos pecuniarios, se concibieron también como espacios claves para comprender, en dicho periodo, el

1 enriquequinteros84@gmail.com / ORCID iD: https://orcid.org/0000-0002-0661-9803 comportamiento corporativo-estamental de sus miembros y las estrategias emprendidas, por estos, a fin de construir y consolidar su poder. En el caso argentino se destacan los análisis globales de Mónica González Fasani² y Roberto Di Stefano ${ }^{3}$ para el espacio rioplatense, de Enrique Normando Cruz para la ciudad de Jujuy ${ }^{4}$ y de Ana Martínez de Sánchez para la de Córdoba. ${ }^{5}$ Significativas también son las conside-

\footnotetext{
González Fasani 2006.

Di Stefano 2002.

4 Cruz 2002, 2009.

5 Martínez de Sánchez 2006.
} 
raciones que Patricia Fogelman esboza sobre la «economía espiritual de salvación» y del papel que en esta, concebida como un plan, les cabía a las cofradías religiosas en tanto espacios desde los cuales, la feligresía, canalizaba sus angustias ante la muerte y las incertidumbres del más allá. ${ }^{6} \mathrm{Y}$ por último, dos estudios de casos, el de María Elena Barral ${ }^{7}$ y el de Dolores Estruch, ${ }^{8}$ el primero situado en el mundo rural rioplatense y el segundo en el escenario urbano jujeño que, a nuestro parecer, dan cuenta de forma clara de la compleja interrelación colonial entre instituciones eclesiásticas, estructuras de poder y redes sociales.

La consideración del fenómeno cofraderil como específica expresión asociativa de una época, no obstante, ha conducido a subestimar su capacidad de adaptación ante una modernidad que no solo auspiciaba la emergencia de novedosas experiencias asociativas (constitutivas a la postre de un decimonónico espacio público) sino que también vaticinaba el repliegue de las prácticas religiosas que las impulsaban. ${ }^{9}$ La desarticulación de estas corporaciones en la América española habría sido impulsada ya hacia finales del siglo XVIII por las medidas de corte ilustrado implementadas por los Borbones que aspiraban a sujetarlas a la jurisdicción civil y depurarlas de sus elementos profanos.

Sin embargo, las revisiones críticas de estos postulados, provistas por las investigaciones que abordaron los efectivos alcances de tales reformas en ambos lados del Atlántico, han brindado nuevas claves interpretativas para comprender la pervivencia de tales experiencias asociativas a través del tiempo, y su dinamismo aún en contextos culturalmente distintos al de su gestación. ${ }^{10}$ Estas consideraciones esbozadas principalmente para el caso de México, Centroamérica y España, y la evidencia documental con la que contamos para el espacio local, nos invitan a pensar que, lejos de constituir resabios de una configuración socio-cultural ya caduca, destinados de una u otra forma a desaparecer, o simplemente a resistir a los embates de las políticas secularizantes, las cofradías y hermandades religiosas experimentaron una suerte de modernización de su fisonomía que les permitió fortalecer el cuadro de las decimonónicas asociaciones religiosas que, sobre todo a partir de la segunda mitad del siglo XIX, asumieron un renovado compromiso con el culto público.

\footnotetext{
6 Fogelman 2000, 2004.

7 Barral 1998.

8 Estruch 2009
}

9 Basta con observar la delimitación temporal de los estudios históricos argentinos sobre cofradías y hermandades religiosas (algunos de los cuales hemos nombrado) para tener una clara idea de hasta qué punto, para los investigadores, estas han perdido protagonismo como instancias asociativas en el transcurso del siglo XIX, opacadas no solo por el dinamismo de un nuevo espacio público y sus experiencias asociativas configuradas en base a modernas coordenadas, sino también por la emergencia de novedosas asociaciones religiosas que parecen expresar mejor el proceso de reconfiguración institucional entre Estado e Iglesia tras la desestructuración del régimen de cristiandad. Esta relativa pérdida de importancia, como se observa concretamente en algunas ciudades del ámbito nacional es una de las principales razones por las que, analíticamente, sus trayectorias históricas y sus transformaciones decimonónicas aun permanecen en penumbras.

10 Véase Carbajal López 2012a; Arias de Saavedra y De Luis 1997; Lempérière 2008; Giménez García 2005; Muñoz y López 2002; Palomo Infante 2004; González García 1984; Serrano 2003.
El análisis de las reconfiguraciones de tales asociaciones de fieles ante la progresiva desarticulación del denominado régimen de cristiandad y la construcción de un nuevo orden caracterizado, en parte, por la redefinición de las relaciones institucionales entre Estado e Iglesia, constituye a nuestro entender, una de las vías posibles para abordar el estudio del proceso de secularización en el espacio local. Por ello, nos proponemos reconstruir la trayectoria histórica de la cofradía Esclavitud del Santísimo Sacramento en la ciudad de Salta, en el periodo que se extiende desde 1774 a 1880, a fin de analizar los cambios y permanencias que se observan en su composición (social y de género), organización interna, regulación jurisdiccional y prácticas devocionales, y la vinculación de dichos factores con el proceso mencionado.

La elección de esta hermandad no es antojadiza, pues se trata de una asociación que, constituida en el año de 1627, extendió su existencia hasta la década de 1930, siendo testigo privilegiado de las modificaciones que operaron en las relaciones entre Estado e Iglesia en la transición del siglo XVIII al siglo XIX. Es además la única de tales experiencias asociativas cuyos diversos libros de ingreso y egresos, y asiento de cofrades, para el periodo comprendido entre 1774 y 1910, se conservan en los repositorios locales. Del resto de las cofradías apenas disponemos de algunos documentos dispersos que solo nos permiten obtener una visión en extremo parcial de sus trayectorias históricas.

Respecto al marco temporal, conviene señalar que el punto de partida de nuestra investigación se encuentra determinado por el año de inicio del libro más antiguo de la mencionada hermandad que se conserva en la actualidad; por el contrario, su punto de llegada no se sujeta a la disponibilidad de fuentes históricas, sino a lo que podríamos considerar como la instancia de culminación de una larga etapa de profundas modificaciones que la afectaron y propiciaron su moderna reconfiguración.

Cofradía Esclavitud del Santísimo Sacramento. Fines del SIGLO XVIII, PRINCIPIOS DEL XIX

En el periodo colonial las cofradías religiosas constituyeron asociaciones de fieles consagradas al culto de una advocación específica y al ejercicio de prácticas caritativas orientadas a la provisión de auxilios espirituales y materiales. En una configuración socio-cultural en la que la preocupación por la vida en el más allá fue una de las principales aflicciones mundanas, se conformaron como espacios formales de adquisición de gracias e indulgencias, que brindaron a los cofrades la posibilidad de reducir el tiempo incierto de permanencia de sus almas en el purgatorio. Complementando dicha provisión, funcionaron también como fuentes de crédito, destinando parte de sus recursos monetarios al auxilio económico de sus miembros. En función de estos servicios, tales corporaciones proliferaron rápidamente en la América española reforzando las solidaridades (materiales y espirituales) de los grupos que emprendieron la conquista del Nuevo Mundo. En la ciudad de Salta, fundada en el año de 1582 en la por aquel entonces Gobernación del Tucumán, las primeras de ellas se instituyeron ya hacia principios del siglo XVII en la primitiva iglesia matriz, para después propagarse en cada uno de los templos pertenecientes a las diversas órdenes religiosas que se establecieron en el incipiente ejido urbano. 
La escasez de fuentes históricas no nos permite reconstruir el derrotero colonial temprano de estas asociaciones; será recién para el siglo XVIII cuando algunos documentos nos permitan observarlas ya consolidadas en el espacio local. En líneas generales, para aquel entonces, se caracterizaron por su variada composición étnica, por una leve preeminencia de aquellas consagradas a diversas advocaciones marianas y por la notoria ausencia de las de carácter gremial, tal como se evidencia también en otras ciudades vecinas. ${ }^{11}$

\section{Cuadro № 1}

\section{Cofradías urbanas. Siglo XVIII, principios del XIX}

\begin{tabular}{|l|l|l|}
\hline \multirow{5}{*}{ Iglesia matriz } & Santísimo Sacramento & $\begin{array}{l}\text { Cofradía sacramental de españoles } \\
\text { compuesta mayoritariamente por } \\
\text { miembros de la elite }\end{array}$ \\
\cline { 2 - 3 } & Nuestra Sra. del Carmen & Cofradía mariana \\
\cline { 2 - 3 } & San Pedro & Cofradía santística de clérigos \\
\cline { 2 - 3 } & Jesús de Nazareno & Cofradía cristológica \\
\cline { 2 - 3 } & Nuestra Sra. del Rosario & $\begin{array}{l}\text { Cofradía mariana con una rama } \\
\text { de españoles y otra de negros y } \\
\text { naturales }\end{array}$ \\
\hline \multirow{4}{*}{ Convento San Francisco } & Benditas Ánimas & - \\
\cline { 2 - 3 } & San Benito de Palermo & Cofradía santística de negros \\
\cline { 2 - 3 } & Nuestra Sra. de la Candelaria & Cofradía mariana de naturales \\
\cline { 2 - 3 } & San Antonio de Padua & Cofradía santística \\
\hline \multirow{2}{*}{$\begin{array}{l}\text { Convento Nuestra Señora } \\
\text { de la Merced }\end{array}$} & Nuestra Sra. de las Mercedes & Cofradía mariana \\
\cline { 2 - 3 } & Nuestra Sra. de los Remedios & $\begin{array}{l}\text { Cofradía mariana, asistencial, de } \\
\text { pardos libres }\end{array}$ \\
\hline Iglesia de la Orden Jesuita & San Baltasar & Cofradía santística de negros \\
\hline
\end{tabular}

Fuente: Elaboración propia.

Durante el periodo colonial, el marco jurídico regulatorio de la erección y funcionamiento de cofradías y hermandades se constituyó a partir de las numerosas disposiciones reales y sinodales que se instrumentaron desde los fueros civiles y eclesiásticos. ${ }^{12}$ Tal entrecruzamiento jurisdiccional respondía a los fines piadosos que las inspiraban, a la naturaleza edificante de sus funciones religiosas, al carácter lego de su composición y a la acumulación, en algunos casos, de cuantiosos bienes donados por sus miembros. El caso de la cofradía Esclavitud del Santísimo Sacramento resulta bastante ilustrativo al respecto. Su institucionalización en el año de 1627, en la iglesia matriz de la ciudad de Salta, fue obra de los miembros del ayuntamiento y del cura beneficiado de la ciudad quienes elaboraron sus estatutos y se erigieron como patronos de la misma con el encargo de costear el alumbrado del octavario que debía celebrarse anualmente después del día de Corpus. La confirmación de las constituciones se produjo ese mismo año con la aprobación concedida por Tomás de Torres, obispo del Paraguay y gobernador electo del obispado del Tucumán. ${ }^{13}$

Instituido en el año de 1264 por el Papa Urbano IV y promovido a mediados del siglo XVI por el Concilio de Trento, el Corpus Christi se convirtió en la principal festividad del mundo católico, máxima expresión del triunfo de la fe

11 Martínez de Sánchez 2006: 73.

12 Ibídem: 88.

13 Archivo y Biblioteca Históricos de Salta (ABHS). Libro de la cofradía Esclavitud del Santísimo Sacramento. 1774-1859. contra la herejía protestante que negaba la presencia real del Cuerpo de Cristo en la Sagrada Forma. ${ }^{14}$ Ampliamente difundido en los reinos españoles, el culto eucarístico se trasladó al nuevo mundo de la mano de los primeros colonizadores, conservando, mediante la fastuosidad propia de la sensibilidad barroca, su función pedagógica ante los devotos de los más variados escenarios. ${ }^{15}$ En ambos lados del Atlántico surgieron también numerosas corporaciones religiosas que, auspiciadas por las autoridades eclesiásticas y civiles, se consagraron a su mayor exaltación. En algunas de las ciudades más periféricas del virreinato del Perú, fue principalmente en el periodo comprendido entre fines del siglo $\mathrm{XVI}$ y mediados del XVII, en el que se instituyeron las primeras cofradías, hermandades y esclavonias sacramentales; en Buenos Aires en 1596, ${ }^{16}$ en Salta (como ya mencionamos) en 1627, en Córdoba en $1628^{17}$ y en Jujuy en $1656,{ }^{18}$ es decir, al poco tiempo de sus respectivas fundaciones, poniendo en evidencia la vinculación entre las directrices de gobierno de la Iglesia católica, las necesidades espirituales de sus primitivos moradores y el arraigo local de la devoción. ${ }^{19}$

Ya desde sus inicios la cofradía sacramental salteña nucleó en su seno a los miembros del primigenio grupo de beneméritos encomenderos quienes asumieron sus principales cargos de gobierno. ${ }^{20}$ No se trató, sin embargo, de una hermandad exclusivamente elitista, pues aún cuando su estipendio de ingreso de cuatro pesos fuese relativamente elevado respecto al de otras, ${ }^{21}$ podían integrarla (y de hecho lo hicieron, aunque de forma minoritaria) los naturales y algunos pobres de la ciudad con la condición de pagar un abono menor al estipulado constitucionalmente..$^{22}$ Contaba también la cofradía con el servicio de algunos negros esclavos de su propiedad, adquiridos por el beneficio de diversos legados testamentarios, a los cuales se les procuraba enseñar, ya desde pequeños, algún instrumento musical para reducir el costo de las funciones religiosas. ${ }^{23}$

El asiento de sus miembros, como puede verificarse igualmente en las hermandades de otras ciudades vecinas, ${ }^{24}$

14 Véase Ramos Alfonso 2006; Timón 2011; Rodríguez de Gracia 2004; Martínez Gil y Rodríguez González 2002.

15 Garavaglia 2002.

16 Núñez y Ruiz-Díaz 2015.

17 Martínez de Sánchez 2006: 76.

18 Estruch 2009: 68.

19 Martínez de Sánchez 2006: 81.

20 Por disposición de las autoridades civiles y eclesiásticas intervinientes en el acto de erección de la cofradía sacramental, su mayordomía, principal cargo directivo, recayó, en el año de 1627, en la persona del Capitán Lorenzo de Céspedes, vecino encomendero casado con Beatriz de Zumárraga, hija del también Capitán Juan de Zumárraga lbarguren participe de la fundación de la ciudad de San Juan de Vera de las Siete Corrientes.

21 Si bien no disponemos de fuentes históricas que nos permitan comparar el estipendio de ingreso de la cofradía sacramental respecto al de otras establecidas también en el espacio local, cabe señalar que, por ejemplo, en la del Carmen con asiento en la Iglesia Matriz de la vecina ciudad de Jujuy, este solo alcanzaba los cuatro reales (Cruz 2009: 64); y en la homónima cofradía sacramental de la ciudad de Córdoba, las contribuciones de los cofrades oscilaron entre un real y un peso (Núñez y Ruiz-Díaz 2015: 329).

22 ABHS. Libro de la cofradía Esclavitud del Santísimo Sacramento. 1774-1859.

23 Archivo Arzobispal de Salta (AAS). Carpeta Visitas pastorales. Informe del obispo Ángel Mariano Moscoso. 1791.

24 Cruz 2013. 
se realizó generalmente de forma grupal por lo que la adscripción del padre y cabeza de familia supuso la de su esposa, sus hijos, y en algunas pocas ocasiones, demás parientes, como así también el personal de servicio de su casa.

Hacia fines del siglo XVIII y principios del XIX, hombres y mujeres nutrieron las filas de la asociación, observándose un relativo equilibrio de género. No obstante, las responsabilidades de unos y otros fueron distintas. El ejercicio de los cargos directivos fue, de forma exclusiva, prerrogativa masculina; a las cofradas, por su parte, les correspondió, sobre todo en las vísperas y transcurso de las jornadas festivas, ocuparse del adorno y decoración de la iglesia matriz, y de la compostura de las flores, las velas y los altares. Algunas de ellas se desempeñaron como las principales colaboradoras de los mayordomos de la corporación, asumiendo el compromiso de realizar las compras de los enseres y utensilios necesarios para las fiestas, organizar las tareas de los esclavos de la cofradía y conchabar a otras mujeres para el labrado de la cera. Una de ellas fue Margarita Antonia Gauna quien, entre 1774 y 1815, tuvo una destacada participación en el seno de la asociación como responsable de sus gastos cotidianos. El importe de los recursos que manejaba osciló, en el periodo, entre los cuatro reales y los cien pesos, esta última cifra nada despreciable si se considera que, en promedio, los ingresos anuales de la hermandad por aquel entonces apenas superaban los mil. Si bien su actuación se halló sujeta al control de los sucesivos mayordomos, gozó de ciertos márgenes de acción que le permitieron, en ocasiones, disponer y determinar el destino de los fondos pecuniarios cofraderiles. En efecto, si bien las cofradías religiosas pueden concebirse como uno de los tantos espacios desde los cuales se expresaron las asimétricas relaciones de género constitutivas de la sociedad colonial, ${ }^{25}$ es posible también observar en su seno el despliegue de ciertas prácticas que, aun fundamentadas en aquel complejo relacional, habilitaban algunas instancias de decisión y participación femenina indispensables para el sostenimiento cotidiano de la estructura organizacional.

Fue también este el periodo en el que la hermandad se robusteció por el ingreso de un importante contingente de comerciantes y funcionarios reales, provenientes de la península y de otras jurisdicciones de la América española que atraídos por la prosperidad económica de la ciudad establecieron residencia en ella. La construcción de una red de relaciones sociales ventajosas mediante el matrimonio y el compadrazgo, y la inserción en los diversos eslabones del comercio mular y de efectos de Castilla, en tiempo de una creciente mercantilización regional, les permitieron vincularse con las beneméritas familias de hacendados y estancieros locales, y encumbrarse social y económicamente. ${ }^{26}$ Fueron algunos de estos nuevos actores sociales quienes, en calidad de mayordomos, elegidos por el vicario foráneo y curas rectores de la iglesia matriz, asumieron la mayor responsabilidad a la que como legos podían aspirar en el seno de la asociación; administrar sus recursos y velar por la mayor solemnidad del culto eucarístico.

\footnotetext{
25 Ibídem.

26 Marchionni 1999.
}

Cuadro № 2

\section{Mayordomos de la Cofradía Esclavitud del Santísimo} Sacramento

\begin{tabular}{|c|c|c|c|c|}
\hline Mayordomos & Periodo & Profesión & Procedencia & Otros cargos \\
\hline Domingo de Frías & $(-)-1773$ & Clérigo & Salta & $\begin{array}{l}\text { Cura rector y vicario } \\
\text { foráneo }\end{array}$ \\
\hline $\begin{array}{l}\text { Miguel Alonso de } \\
\text { Visuara }\end{array}$ & $1773-1775$ & Clérigo & Salta & $\begin{array}{l}\text { Comisario de la Santa } \\
\text { Cruzada; Colector de } \\
\text { Rentas Eclesiásticas }\end{array}$ \\
\hline Enrique Cuello & $1775-1788$ & Clérigo & Salta & - \\
\hline $\begin{array}{l}\text { Miguel Vicente } \\
\text { de Solá }\end{array}$ & $1788-1790$ & Comerciante & $\begin{array}{l}\text { Buenos } \\
\text { Aires }\end{array}$ & - \\
\hline $\begin{array}{l}\text { Manuel de la } \\
\text { Cámara }\end{array}$ & $1790-1791$ & Clérigo & Salta & $\begin{array}{l}\text { Colector de Rentas } \\
\text { Eclesiásticas }\end{array}$ \\
\hline $\begin{array}{l}\text { Apolinario } \\
\text { Usandivaras }\end{array}$ & $1791-1794$ & Comerciante & Córdoba & $\begin{array}{l}\text { Regidor }(1789 ; 1792) ; \\
\text { Alférez (1794) }\end{array}$ \\
\hline Antonio de Figueroa & $1795-1800$ & Comerciante & Córdoba & $\begin{array}{l}\text { Alcalde de } \text { 1ํ voto } \\
(1773 ; 1784 ; 1795) ; \\
\text { Alcalde de 2ํㅡoto (1766); } \\
\text { Justicia Mayor (1778); } \\
\text { Coronel de Milicias (1780); } \\
\text { Síndico Ecónomo del } \\
\text { Convento San Francisco } \\
(1780)\end{array}$ \\
\hline Marcos Beeche & $1802-1810$ & Comerciante & $\begin{array}{l}\text { Bilbao } \\
\text { (España) }\end{array}$ & Regidor (1802) \\
\hline $\begin{array}{l}\text { Ignacio de } \\
\text { Gorostiaga }\end{array}$ & $1802-1810$ & Comerciante & $\begin{array}{l}\text { Guipúzcoa } \\
\text { (España) }\end{array}$ & $\begin{array}{l}\text { Mayordomo de Obras } \\
\text { (1798); } \\
\text { Administrador General de } \\
\text { Correos (1808) }\end{array}$ \\
\hline
\end{tabular}

Fuente: Elaboración propia.

El desempeño del cargo de mayordomo por los comerciantes "recién llegados», fenómeno también observado en otras ciudades ${ }^{27}$ y que, en el espacio local, no se redujo a la referida hermandad, ${ }^{28}$ puede concebirse como una instancia más en las carreras de meritos de estos agentes sociales, una instancia a través de la cual reforzaron su prestigio en el marco del proceso de reconfiguración que, hacia fines del siglo XVIII, experimentó la elite salteña. ${ }^{29}$ Como tales, se pusieron al frente de una de las asociaciones religiosas más antiguas, conformada por los descendientes de los beneméritos primeros pobladores y por los que, como ellos, se avecindaron en una ciudad, diferente a la de su origen, a fin de satisfacer sus intereses materiales y espirituales.

Resulta interesante observar que mientras en el periodo de 1773-1788 la mayordomía de la hermandad fue ejercida por agentes eclesiásticos, en el de 1788-1810, salvo por un breve intervalo (1790-1791), su ejercicio le correspondió a los referidos comerciantes. Su designación en el cargo respondió a diversos motivos, entre los cuales cabe destacar; su reconocida inserción social, y la pericia empresarial y administrativa adquirida por su oficio, que podía garantizarle a la asociación una equilibrada gestión de recursos y el beneficio de proveerse de los productos que, útiles a la solemnidad del culto, formaban

27 Fogelman 2000; Estruch 2009.

28 Fueron también comerciantes peninsulares quienes asumieron la mayordomía de las cofradías de Benditas Ánimas del Purgatorio y de la de Nuestra Señora del Rosario con asiento en la Iglesia Matriz de la ciudad hacia finales del siglo XVIII y principios del XIX. AAS. Carpeta Visita Pastorales. Informe del obispo Ángel Mariano Moscoso. 1791.

29 Marchionni 1999. 
parte de las habituales operaciones que estos comerciantes mantenían con sus socios porteños, potosinos y limeños.

Un caso paradigmático es el de Antonio Figueroa quien dedicado al comercio mular llegó a acumular una importante fortuna que le permitió forjar una notable trayectoria de ascenso social. De origen cordobés, se vinculó en Salta con los Toledo Pimentel, familia propietaria del Valle del Lerma, ${ }^{30}$ logrando a partir de entonces ocupar puestos claves en el cabildo salteño. ${ }^{31}$ Fue además coronel de milicias, comandante general de la frontera, gobernador de armas, teniente de gobernador y presidente de la Junta Municipal de Temporalidades. Casado con María del Carmen Toledo Pimentel tuvo una vasta prole a través de cuyos matrimonios supo consolidar a los suyos en el escenario local, enlazándose, de forma simultánea, con familias de elite avecindadas en la ciudad ya en el siglo XVII, principalmente con los Fernández Cornejo y con prósperos comerciantes recién llegados de destacada participación en el ayuntamiento en las postrimerías del periodo colonial. ${ }^{32}$

La fortuna de Antonio le permitió hacerse poseedor de importantes propiedades como la hacienda del Bañado que perteneció a la Orden de los Jesuitas hasta su expulsión. Por esta, como por otras tierras que también adquirió, pudo concentrar, como pocos comerciantes supieron hacerlo, un amplio conjunto de actividades vinculadas al tráfico mular, actuando como invernador, apoderado, fletador y dueño de las tropas de las mulas que conducía a diversas plazas comerciales. ${ }^{33}$

Como Alcalde Ordinario, Antonio contribuyó con las obras de reconstrucción del cabildo de la ciudad, como así también con la reparación del templo de la iglesia matriz y la del convento San Francisco, desempeñándose además como síndico ecónomo de este ultimo e integrando la Venerable Tercera Orden que funcionaba en el mismo.

Su asiento como hermano de la cofradía del Santísimo Sacramento en el año de 1779 se produjo tiempo después de su avecindamiento en la ciudad y de su enlace con María del Carmen Toledo Pimentel; su designación como mayordomo de la corporación en 1795. Contaba ya para entonces con una solida red comercial; con estrechos vínculos entablados con los miembros de la elite local mediante su matrimonio y los de sus hijos; con un importante patrimonio inmobiliario que incluía propiedades urbanas y rurales; y con una notable trayectoria política que comprendió el desempeño de diversos cargos en el ayuntamiento.

Su nombramiento como "hermano mayor» de la referida hermandad coincidió con la asunción de sus funciones en calidad de Alcalde de 1ㅇvo voto. Para entonces el cabildo se encontraba conformado, entre otros, por su hijo Francisco

30 Francisco Toledo Pimentel, suegro de Antonio de Figueroa, contaba hacia el año de 1780 con una importante fortuna calculada en 35.280 pesos que comprendía un vasto patrimonio rural y una importante cantidad de ganado que remitía a distintas plazas comerciales. Gozaba también de gran prestigio por sus estrechos vínculos familiares con Fernando Toledo Pimentel, sobrino del Virrey del Perú. Avecindado en la ciudad de Salta en la primera mitad del siglo XVIII formó parte del cabildo local en diversas oportunidades, destacándose también por su desempeño en las milicias urbanas.

31 Alcalde de 1ㅇ voto; 1773, 1784; 1795; Alcalde de 2ㅇvoto; 1766

32 Marchionni 2000: 293-294.

33 Coronel, Mariela. 2012. Comercio, familia y redes de relaciones. Antonio de Figueroa, Salta a fines del siglo XVIII. Tesis Magister, inédita, Universidad de Huelva: 63.
Javier y algunos de sus yernos, Antonio San Millán y Apolinario Usandivaras. Sus relaciones con la Iglesia eran también sólidas, tanto con la orden seráfica, como ya mencionamos, como con el clero secular al cual pertenecía otro de sus hijos, José Gabriel, que había iniciado ya, para fines del siglo XIX, una prometedora carrera eclesiástica. ${ }^{34}$

A diferencia de la homónima cofradía con asiento en la iglesia matriz de la vecina ciudad de Jujuy, en la que el ejercicio de su diputación precedió generalmente al de su mayordomía, ${ }^{35}$ no se observa en la de Salta una similar trayectoria honorífica; por el contrario, en la mayoría de los casos, los comerciantes designados como sus mayordomos solo se registraron como miembros de la asociación una vez en el ejercicio del cargo. Este no es un dato menor si consideramos que hacia finales del siglo XVIII y principios del XIX, la cofradía, como mencionamos anteriormente, se constituía por las figuras más prominentes y conspicuas del escenario local, hacendados descendientes de las beneméritas familias y exitosos «comerciantes recién llegados» que, como ellos, reunían, potencialmente, las condiciones que ameritaba tal designación. La explicación de este fenómeno no resulta sencilla debido, principalmente, a la escasez de las fuentes documentales que nos permitan abordarla satisfactoriamente. No obstante, el informe elaborado por el obispo Ángel Mariano Moscoso, en el año de 1791, sobre las cofradías de la ciudad de Salta con asiento en la iglesia matriz, nos brinda algunas respuestas. El cuadro general que expone a partir de sus observaciones da cuenta de que, de un total de seis cofradías inspeccionadas en dicha oportunidad, solo tres (la del Santísimo Sacramento, la de Nuestra Señora del Carmen y la de Benditas Ánimas) gozaban de buena salud, hallándose las restantes sujetas a una difícil situación por la falta de autoridades competentes que las dirigieran, la exigüidad de sus recursos y las irregularidades en el manejo de los mismos. Respecto a las tres primeras, cabe destacar que no se trató de hermandades dotadas de un importante caudal económico, por lo que sus capitales, dispuestos en calidad de créditos, tuvieron una limitada gravitación en el circuito financiero, sobre todo en comparación con los principales que administraron otras instituciones locales, entre ellas, el convento de San Francisco y el Hospital de San Andrés. ${ }^{36}$ Ante este panorama, el obispo ordenó,

\footnotetext{
34 Caretta 1999.

35 Estruch 2009: 61-78.
}

36 Para el año de 1791, los capitales de las cofradías de la Iglesia matriz invertidos en préstamos censitarios apenas alcanzaban el importe de $\$ 3.450$, distribuidos de la siguiente manera; $\$ 1.000$ correspondientes a la del Santísimo Sacramento; $\$ 1000$ a la de San Pedro; $\$ 750$ a la de Nuestra Señora del Carmen; $\$ 500$ a la de Benditas Ánimas; y $\$ 200$ a la de Jesús de Nazareno. Por su parte, la del Rosario solo disponía de un fondo de $\$ 23$ que se hallaban en poder del cura y vicario de la ciudad, Gabriel Gómez Recio. Estos importes se revelan exiguos respecto a los que el convento de San Francisco y el hospital de San Andrés administraban por aquel entonces. Así por ejemplo, los principales del primero invertidos en el año de 1782 alcanzaban la suma de $\$ 5.614$, y los del segundo, para el año de 1805 , los $\$ 9.000$. (AAS. Carpeta "Hospital de San Andrés". 1805). Los recursos crediticios de las cofradías locales también fueron reducidos ante aquellos que, promediando la segunda mitad del siglo XVIII, administraba la hermandad de Nuestra Señora de los Dolores y Benditas Ánimas del Purgatorio, con asiento en la iglesia catedral de la ciudad de Buenos Aires, que, por ejemplo, para el año de 1776, disponía de varios censos de más de \$1.000 (Fogelman 2000: 14). 
en algunos casos, la estricta sujeción de los administradores legos de cofradías a los designios del vicario y curas rectores de la iglesia matriz, y en otros, desplazándolos, reservó el gobierno de estas asociaciones a los agentes eclesiásticos por la consideración de que sus funciones religiosas y administración se ejecutarían mejor de esta manera. ${ }^{37}$

En líneas generales entonces, se evidencia hacia fines del periodo colonial un relativo declive de las cofradías y hermandades locales, producto quizás, como se ha sugerido para otros espacios, del paulatino abandono de ciertas prácticas religiosas que, para aquel entonces, empezaron a perder sentido. ${ }^{38}$ Si ello fue así, podemos pensar, consecuentemente, que el ejercicio de sus mayordomías como variable de prestigio experimentó también sus primeros síntomas de decadencia, fenómeno azuzado, probablemente, por la pretensión del clero de incrementar su injerencia y control sobre algunas de estas asociaciones. En el caso especifico de la cofradía Esclavitud del Santísimo Sacramento, la elección de un foráneo como su mayordomo, práctica sugerida, circunstancialmente, solo en caso de no hallar entre sus miembros a personas competentes, quizás constituya entonces la expresión de la disminución del atractivo del cargo, más que de la ausencia de cofrades dotados de las competencias y virtudes que su ejercicio exigía.

Por su parte, la diputación de la hermandad presentaba también sus propias particularidades. Cargo de menor relevancia sobre el que recayó principalmente la labor de recoger las limosnas de los fieles, fue desempeñado, durante el periodo, por un heterogéneo grupo compuesto por algunos miembros de la elite local y otros que no compartían sus privilegios. Entre los primeros, se destaca la presencia de Bernabé Saravia perteneciente a una de las familias avecindada en la ciudad a principios del siglo XVIII que aun perdiendo representación en el cabildo local conservó importantes espacios de poder; ${ }^{39}$ entre los segundos, Luis Refojos, pulpero que solo adquirirá mayor prestigio social luego de la revolución de 1810.

El mayordomo, principal autoridad cofraderil, concentraba en sus manos un amplio abanico de deberes y obligaciones. Comandando el cuerpo de los hermanos, se constituía en el síndico ecónomo responsable de la administración de los recursos y bienes de la asociación, debiendo garantizar, durante el periodo de su gestión, la mayor solemnidad de las fiestas y el pago de las misas por el bienestar de los cofrades vivos y difuntos. Con la ayuda del diputado registraba diariamente, en el libro de cuentas, los ingresos y egresos pecuniarios, y cuando en ocasiones los fondos acumulados no eran suficientes para costear los gastos realizados, compensaba él, con sus aportes, dichos excesos. ${ }^{40}$

El control de la labor de las autoridades cofraderiles de la hermandad sacramental fue prerrogativa exclusiva de los agentes eclesiásticos. Los mayordomos debían presentar anualmente las cuentas de cargo y data, con detalle prolijo de todos los movimientos efectuados, ante los curas recto-

37 AAS. Carpeta Visitas pastorales. Informe del obispo Ángel Mariano Moscoso. 1791.

38 Di Stefano 2002: 40-41.

39 Marchionni 1999: 185.

40 ABHS. Libro de la cofradía Esclavitud del Santísimo Sacramento. 1744-1859. Balance de ingresos y egresos del presbítero Miguel Alonso de Visuara. 1775. res de la iglesia matriz; consultarles acerca de la conveniencia, o no, de la inversión o el destino de sus recursos; confeccionar, al final de su gestión, un inventario de los bienes de la asociación, señalando el incremento de los mismos con los que habían contribuido; y efectivizar las órdenes del obispo dispuestas en ocasión de su visita a los libros de la cofradía. ${ }^{41}$

Las fuentes de las que disponemos hasta el momento nada nos informan acerca de las posibles intervenciones del poder civil en la regulación de las actividades de esta hermandad, ni de la mayor o menor presencia de sus oficiales en las juntas de hermanos a partir de las ordenanzas de los Borbones, como si se verificó en otras ciudades vecinas..$^{42}$ El patronato que el cabildo local asumió desde la fundación de la misma, pareció limitarse, hacia finales del siglo XVIII, al pago de la cera para el alumbramiento del octavario del Corpus; y, en el caso de la elección de mayordomos y diputados, a la confirmación de una decisión que generalmente resolvió el obispo de la diócesis.

El momento crucial en la vida de la cofradía lo constituía la festividad del Corpus Christi, celebrada anualmente en los primeros días del mes de junio. Ante la ocasión, el mayordomo, en colaboración con las "esclavas del Santísimo», debía procurar la decoración del templo; la elaboración de las velas; el arreglo del palio, las camaretas, los candeleros y el cajón de la demanda; la compra de incienso, pólvora y cohetes, ramos de flores y telas suntuarias; el contrato de cantores, violinistas, arperos y demás músicos; el pago de los sermones y las misas. La fiesta del Santísimo Sacramento suponía el montaje de un escenario sagrado que trascendía el templo de la iglesia matriz para transformar la plaza principal y las calles que la circundaban, por donde la sagrada custodia, acompañada por el cortejo procesional, irradiaba las bondades del culto, contribuyendo a «la edificación de los fieles y propendiendo al bien público».. ${ }^{43}$

En el periodo comprendido entre 1774 y 1810, en promedio, los gastos de la cofradía en la festividad del Corpus alcanzaban los \$250 anuales, constituyendo su principal desembolso las misas oficiadas por el clero, seguido, en orden descendiente, por: la compra de la cera, y el servicio de su labrado; y el contrato de los músicos que acompañaban la función religiosa. Tales costos, de carácter permanente, se afrontaban con el producto de las limosnas recogidas los jueves y domingos en la puerta del templo y en sus alrededores. La gestión de los comerciantes fue notoriamente eficaz a juzgar por los sucesivos saldos positivos que arrojaron sus balances anuales en el periodo en cuestión, que le permitieron a la asociación cumplir con sus obligaciones cultuales y además, destinar, circunstancialmente, estos remanentes (aunque escuetos) para la realización de otras obras piadosas. ${ }^{44}$

41 ABHS. Libro de la cofradía Esclavitud del Santísimo Sacramento. 1774-1859.

42 Martínez de Sánchez 2006: 87.

43 AAS. Disposiciones del obispo Juan de Serricolea del Tucumán sobre la misa de renovación en la ciudad de Salta. 1730.

44 Así por ejemplo, a finales de 1796, el obispo Ángel Mariano Moscoso disponía que, del saldo de \$558 resultante a favor de la asociación, \$500 se destinarán para la prosecución del trabajo de reconstrucción de la iglesia matriz. (ABHS. Libro de la cofradía Esclavitud del Santísimo Sacramento. 1774-1859). Respecto a los saldos de la asociación, debemos señalar que estos, aun cuando 
Las autoridades civiles de la ciudad también debían contribuir a la solemnidad del culto eucarístico, con su presencia y recursos. No obstante, los aportes del cabildo y del gobernador intendente concedidos a la hermandad para el alumbrado del octavario del Corpus se caracterizaron por su irregularidad, cada vez más pronunciada conforme transcurrió el decenio de 1800, y que en promedio, según los registros de los libros de la asociación, no superaron los $\$ 30$ anuales, invertidos principalmente en el pago de misas y sermones. ${ }^{45}$

En definitiva, hacia fines del periodo colonial, todavía la hermandad sacramental podía exhibir cierto decoro y solemnidad en su función principal. La presencia en sus filas de exitosos comerciantes foráneos le imprimió, al igual que en tantas otras jurisdicciones, un renovado impulso además de garantizarle el servicio de un personal hábil en la gestión de sus bienes. Sin embargo, algunas cosas, lentamente, empezaban a cambiar. A la posible dificultad de hallar entre sus miembros a quien la dirigiera, se le sumaba un relativo declive de la advocación que la impulsaba. Ya en el año de 1761 el juez eclesiástico, Francisco Castellanos, advertía el notorio y público desprecio de los hombres respetables de la ciudad respecto al Santísimo Sacramento, quienes no cumpliendo con sus mandatos pedagógicos y de ejemplaridad, preferían asistir a las casas de truco antes que al templo. Señalaba asimismo, sin saberlo, los primeros síntomas de futuras transformaciones; la popularización del culto eucarístico y la feminización de la religión;

pues siendo la institución del Santísimo Sacramento de la Eucaristía el principal artículo de fe, en el que nuestro señor renovando su excesivo e infinito amor con los hombres, se manifiesta a las puertas de su santa iglesia a bendecirlos, sin embargo del notorio y publico desprecio e ingratitud (...) y no aparece hombre alguno en tales días, y solamente la gente plebe manifiesta su agradecimiento con su devota asistencia (...) y que estando frecuentando cada domingo en la tarde la explicación de la doctrina cristiana es vano el día en que asisten solas mujeres, por lo que sin duda se consideran todos los hombres españoles por sabios en todos los misterios necesarios que deben saber y entender; pues aunque no los ignoren deben con su asistencia dar el buen ejemplo a otros que carecen por su ignorancia y falta de educación y enseñanza para excitarlos a que asistan a la doctrina cristiana además de que todos están obligados a concurrir. ${ }^{46}$

\section{UN PERIODO DE TRANSICIÓN, 1810-1862}

Tras la disolución del orden colonial en las primeras décadas del siglo XIX, las elites dirigentes del proceso revolu-

suficientes para afrontar los gastos cultuales y los de las misas por los almas de los cofrades vivos y difuntos, fueron reducidos en relación a los que algunos años antes resultaban de las cuentas de cargo y data de la ya mencionada hermandad porteña de Nuestra Señora de los Dolores y Benditas Ánimas del Purgatorio, cuyos importes totales oscilaban entre los $\$ 2.500$ y $\$ 3.000$ anuales en 1758 y 1759 (Fogelman, Patricia. 2000: 12). En el periodo comprendido entre 1774 y 1810, los ingresos de la cofradía sacramental distaban mucho de los de aquella, pues apenas promediaban los $\$ 500$ anuales.

45 ABHS. Libro de la cofradía Esclavitud del Santísimo Sacramento. 1774-1859.

46 AAS. Auto del Juez Eclesiástico, Francisco Castellanos. 1761. cionario debieron definir la naturaleza de sus relaciones con la Iglesia, sus agentes y corporaciones. Las nacientes autoridades civiles, lejos de prescindir de los servicios del clero se valieron de su ascendiente sobre las conciencias de la feligresía para construir y consolidar un nuevo orden social y político, amenazado prematuramente por las particularidades de las convulsiones de la guerra, sus costos y movilizaciones en el escenario local. ${ }^{47}$

En este contexto político y en el marco de una modernidad que, al menos durante los primeros años de vida independiente, no implicó una ruptura con la tradición colonial de unanimidad cristiana ${ }^{48}$ o, en otras palabras, de una modernidad que se expresó a un ritmo propio, las cofradías y hermandades religiosas locales experimentarán una serie de transformaciones que redefinirán su fisonomía. Dichos cambios se vincularon más con las modificaciones que se produjeron en el ámbito de las prácticas religiosas, que, como en otros Estados americanos, con el alcance de los programa liberales/anticlericales emprendidos por las elites republicanas a fin de disminuir el poder de estas corporaciones eclesiásticas. ${ }^{49}$ Asimismo, aunque algunas de ellas desaparecerán durante el transcurso de este periodo, y las que sobrevivieron lo hicieron signadas por una marcada decadencia, no se trató de una crisis de carácter definitivo para este tipo de experiencia asociativa, pues ya en la segunda mitad del siglo XIX reaparecerán adaptándose a las necesidades espirituales del laicado decimonónico y a los intereses del clero local.

\section{Panorama asociativo posrevolucionario}

Del conjunto de doce cofradías coloniales consignadas en el Cuadro №1, solo seis (Santísimo Sacramento, Benditas Ánimas, Nuestra Señora del Rosario, Nuestra Señora del Carmen, Nuestra Señora de los Remedios y San Benito) lograron sobrevivir, con distinta suerte, hasta la década de 1860. De las restantes, algunas se extinguieron ya hacia finales del siglo XVIII (San Pedro, San Baltasar Nuestra Señora de la Candelaria y Nuestra Señora de la Merced) y otras en las primeras décadas del XIX (Jesús de Nazareno y San Antonio de Padua).

A pesar de los esfuerzos del clero local, ${ }^{50}$ el panorama cofraderil decimonónico de este periodo se caracterizó por un marcado estancamiento, fundándose entre 1810 y 1862 una sola cofradía, la de Nuestra Señora del Carmen, con asiento en el convento de Monte Carmelo, que complementó el escaso número de aquellas con origen colonial.

Al margen de estas experiencias asociativas y a diferencia del impulso asociativo verificado en otras ciudades del ex-virreinato rioplatense, ${ }^{51}$ en la de Salta, fueron considera-

47 Caretta y Marchionni 2000.

48 Ibídem: 115.

49 Palomo Infante 2004; González García 1984.

50 Hacia fines de la década de 1850, las autoridades eclesiásticas locales promovieron la fundación de las cofradías del Sagrado Corazón de Jesús, y la del Santísimo Salvador y Bienaventurada Virgen del Milagro, en la iglesia matriz de la ciudad. No obstante, ambos proyectos fracasaron. La primera acabó integrándose en la del Santísimo Sacramento como una obra pía, mientras la segunda no llegó siquiera a erigirse.

51 Di Stefano 2002. 
blemente escasas las asociaciones (religiosas o no) que durante este periodo se constituyeron. En la década de 1830 se conformarán la Sociedad La Libertad y la Sociedad de Beneficencia compuestas, respectivamente, por los hombres y mujeres de la elite local al objeto de "fomentar en la juventud salteña la ilustración en artes y ciencias, y aun dar hojeadas sobre la moral pública». ${ }^{52}$ Recién algunos años más tarde, hacia mediados de 1850, algunos tímidos proyectos asociacionistas se concretarán nuevamente, permitiendo la emergencia de La Asociación y La Sociedad de Navegación que surgieron como espacios de discusión acerca del proceso de organización nacional emprendido en el aquel entonces y las posibilidades económicas que este le ofrecía a la provincia. En el mismo decenio se produjo además la fundación del Club de Lectura y Recreo, y el Club 20 de Febrero, de carácter elitista y masculino como las anteriores, pero que se distinguieron por sus fines culturales y recreativos.

En líneas generales, el conjunto de las asociaciones mencionadas, tanto las cofradías y hermandades como aquellas desprovistas de cualquier fin espiritual/ religioso, mantuvieron una estrecha dependencia respecto a las autoridades eclesiásticas y civiles locales por lo que lejos de conformarse como instancias criticas de ambos poderes, fueron, al menos en este periodo, funcionales a sus intereses.

\section{La cofradía Esclavitud del Santísimo Sacramento. Jurisdicción y autoridades.}

Hacia fines del siglo XVIII, los Borbones acentuaron su control sobre el funcionamiento de cofradías y hermandades religiosas, emprendiendo un plan general de reformas que, lejos de pretender erradicarlas, aspiraba a sujetarlas a su autoridad en detrimento de la eclesiástica, purificarlas de prácticas gentilicias y gastos superfluos e imprimirles un renovado carácter religioso vinculado con el ejercicio de la beneficencia pública. ${ }^{53}$ Además de sus alcances diversos, estas medidas, sintomáticas de una primera instancia de secularización, ${ }^{54}$ se materializaron de forma diferencial tanto en la península como de este lado del Atlántico. Así, por ejemplo, mientras en Sevilla el clero fue expulsado de los cabildos cofradieros, en Nueva España solo perdieron su calidad de presidentes de dichas juntas en beneficio de los jueces reales. ${ }^{55}$ En Córdoba del Tucumán también se efectivizó la presencia de tales ministros en las reuniones de cofrades, mas las disposiciones regias sobre el control de sus bienes no resultaron eficaces por tratarse de asociaciones dotadas de escasos recursos. ${ }^{56}$ Las de Salta, inmersas en un contexto de relativa decadencia, probablemente tuvieron la misma suerte. Ya hicimos referencia incluso a las órdenes dispuestas por el obispo Moscoso en el año de 1791 orientadas a incrementar el control eclesiástico sobre las cofradías de la iglesia matriz de la ciudad, lo que da cuenta de la continua intervención del clero en la regulación de estas corporaciones aun en el marco de las reformas menciona-

52 ABHS. Reglamento de la Sociedad Protectora de la Educación, La Libertad. 1836.

53 Carbajal López 2012a.

54 Lempériere, Annick. 2008: 20.

55 Carbajal López 2012b.

56 Martínez de Sánchez 2006: 87. das. No obstante, la «secularización borbónica» ${ }^{57}$ puesta en marcha, trazó un programa de medidas que será retomado por los líderes revolucionarios en el proceso de redefinición de sus relaciones con la Iglesia, y que como veremos a continuación, afectará a las cofradías y hermandades locales.

Luego de la revolución de 1810 las autoridades civiles salteñas, en uso de las facultades correspondientes al ejercicio del vice-patronato, compartirán, junto al clero, ciertas prerrogativas en la regulación de estas asociaciones. El ejecutivo provincial será el encargado de autorizar algunas de las actividades que, propuestas por los cofrades, se vincularán a diversas expresiones públicas de fe. Así por ejemplo en el año de 1826, el Provisor y Vicario General de la diócesis, José Gabriel de Figueroa, sujetará su autorización a la solicitud realizada por el mayordomo de la cofradía de Nuestra Señora del Rosario «para sacar al vía cruz el día de Ramos» a la anuencia del gobernador de la provincia, Juan Antonio Álvarez de Arenales, quien sin mayores recelos, aprobará la propuesta con la única condición expresa de que no se realizara por la noche, dejando en manos de las autoridades eclesiásticas la resolución de toda otra cuestión que pudiera suscitarse. ${ }^{58}$

La intervención del poder civil también se verificó en algunas otras instancias aun más decisivas; la fundación de cofradías y hermandades, y la supervisión de las resoluciones de sus juntas. Así por ejemplo, fue al ejecutivo provincial a quien le correspondió, en calidad de autoridad suprema de la jurisdicción, aprobar el establecimiento de una cofradía consagrada a la Virgen de Nuestra Señora del Carmen en el convento de Monte Carmelo, luego de que sus estatutos fueran sancionados, a fines de la década de 1840, por el provisor y gobernador del obispado. ${ }^{59}$

Bajo este auspicio, se hizo también efectiva la antigua ordenanza colonial que prescribía la presencia de un ministro civil en las reuniones de cofrades, representado, en el caso de la referida hermandad, en la figura de un juez designado por el gobernador que, al menos durante el periodo comprendido entre 1848 y 1855 , refrendó cada uno de los acuerdos y elecciones de autoridades dispuestos en sus juntas. ${ }^{60}$

No disponemos para la cofradía del Santísimo Sacramento de documentos que den específica cuenta de este tipo de entrecruzamiento jurisdiccional. Sin embargo, no son datos menores que quienes desempeñaron su mayordomía desde 1810 a 1848, fueran todos personajes vinculados al gobierno civil por el ejercicio de cargos públicos, y que su elección como mayordomos de la hermandad y la revisión de su gestión administrativa continuará siendo prerrogativa eclesiástica.

\section{Di Stefano 2011}

58 AAS. Carpeta Asociaciones. Solicitud del mayordomo de la cofradía del Rosario. 1826

59 AAS. Carpeta Asociaciones. Constituciones de la cofradía de Ntra. Sra. del Carmen del convento de Monte Carmelo. 1848.

60 Cabe destacar, en este caso, que quienes oficiaron como ministros civiles en dichas juntas fueron también cofrades de la hermandad. Es el caso, por ejemplo, del Coronel Manuel Antonio Saravia que en el año de 1848, además de desempeñarse como tal, asumió el cargo de mayordomo mayor de la Virgen con el encargó de pagar el sermón y el coro en el día de la función principal. AAS. Carpeta Asociaciones. Actas de la cofradía de Nuestra Señora del Carmen. 1848-1855. 
Durante la primera mitad del siglo XIX, la dirección de la hermandad sacramental fue tarea exclusiva de agentes laicos. Desde 1813 a 1817 la mayordomía recayó en Luis Refojos, pulpero perteneciente a los sectores sociales medios cuya designación en el cargo coincidió con su desempeño como Mayordomo de Propios y Alcalde de Barrio, ${ }^{61}$ y quien, a diferencia de sus predecesores y sucesores, presentaba ya para aquel entonces ciertas credenciales de servicio en beneficio de la asociación, pues había ejercido anteriormente el empleo de diputado encargado de la recolección de limosnas.

Transcurridos dichos años y hasta fines de la década de 1840, la cofradía quedará en manos de la familia González de Hoyos, perteneciente al sector de la elite más tradicional, propietaria de tierras en el Valle de Lerma y en la Frontera Este, a la que la revolución les valió la oportunidad de recuperar algunos de aquellos espacios de poder de los que habían sido apartados tras el arribo los de exitosos comerciantes foráneos a los que nos referimos en el apartado anterior. ${ }^{62}$ De hecho, durante este periodo, la dirección de la hermandad fue una suerte de empresa familiar coordinada, sucesivamente, por Hermenegildo González Hoyos (con una destacada participación en el cabildo de la ciudad en las primeras décadas del siglo XIX ${ }^{63}$ ) y su hijo, Camilo, vinculados familiarmente con algunos personajes de notorio capital social, político y económico del escenario local. ${ }^{64}$ Como generalmente había sucedido, Hermenegildo inició su gestión administrativa al frente de la hermandad sin formar parte de ella en calidad de cofrade, asentándose recién como tal, junto a su familia, un lustro después de su nombramiento. En este caso, son más evidentes los indicios de que el cargo de mayordomo ya no revestía la importancia de antaño. En primer lugar porque la asociación atravesaba por aquel entonces una severa crisis económica acompañada de una marcada disminución del número de sus asientos; y en segundo, porque había dejado de ser una asociación mixta y elitista para transmutar en una de carácter femenino y popular.

El monopolio de la mayordomía en manos de prominentes figuras laicas durante este periodo, más que vincularse a un proyecto secularizador decimonónico emprendido por los propios cofrades y/o las autoridades civiles, y orientado a desplazar al clero de las instancias de poder y decisión de estas corporaciones religiosas, como sucedió por ejemplo en Sevilla hacia fines del siglo XVIII y principios del XIX, ${ }^{65}$ fue probablemente el resultado de un tácito acuerdo entre los agentes eclesiásticos y su feligresía. Los fondos de la hermandad sacramental, aunque escasos, se constituyeron en

61 Marchionni 1999: 202.

62 Marchionni 1999: 185.

63 Regidor en 1808; Alcalde de 10 voto en 1813; Elector para cabildante en 1817, 1818, 1819, 1820; y Procurador de la ciudad en 1817 y 1819 , en simultáneo a su desempeño en el cargo de mayordomo de la cofradía sacramental.

64 Entre ellos, Juan Antonio Álvarez de Arenales, militar de destacada participación en las guerras de la independencia y gobernador de la provincia entre 1824 y 1827, y Evaristo Uriburu, acaudalado comerciante con una importante trayectoria política como presidente de la legislatura local y como gobernador delegado en diversas oportunidades; ambos casados con mujeres de la familia Hoyos.

65 Carbajal López 2012b: 3-33. una suerte de reserva para los canónigos, diáconos y sacristanes que celebraban y solemnizaban los oficios sagrados en un periodo de tiempo en el que las rentas eclesiásticas se revelaron exiguas. ${ }^{66}$ Aún más, el ejercicio de la mayordomía por un notable local, en el marco de la crisis económica que experimentó la cofradía durante la primera mitad del siglo XIX, revalidó la condición colonial de suficiencia que se les exigía a sus titulares, ${ }^{67}$ desempeñándose entonces no solo como simples administradores, sino también como sostenedores del culto sagrado, garantizándolo con sus propios aportes. ${ }^{68}$ Como tales continuaron sujetos al control del clero local, que en última instancia, verificaba y, autorizaba o desautorizaba el estado general de las cuentas y balances. ${ }^{69}$

Hacia el año de 1848, luego de más de medio siglo de dirección seglar, el presbítero Gabriel Díaz asumirá el cargo de mayordomo de la asociación, iniciando de esta forma una modalidad de gestión (destinada a perdurar) que se caracterizó por la concentración de dicho oficio y el de capellán en un representante del clero. A partir de entonces fueron los agentes eclesiásticos los encargados de atender los asuntos mundanos y espirituales de la cofradía y sus miembros. Lejos de suscitar algún tipo de conflicto, esta modificación fue el resultado natural de la progresiva deserción del componente masculino de la elite de las filas de la hermandad y, sobre todo, de su resistencia a dirigirla.

\section{Composición y economía}

Como habíamos anticipado, será durante la primera mitad del siglo XIX cuando la composición numérica, social y genérica de la cofradía experimente una serie de profundas transformaciones que propiciarán la mutación de su carácter. En primer lugar porque se produjo una sensible disminución del número de sus miembros. Mientras entre 1774 y 1810 se registró la inscripción de 386 personas, entre 1811 y 1859 la cifra menguó a 225; en promedio, entonces, del primer al segundo periodo, el número de inscripciones anuales se redujo de 10 a 6, observándose además una notoria preeminencia de la modalidad de asiento individual en detrimento de la grupal. ${ }^{70}$ En segundo, porque aumentó notoriamente, en las filas de la hermandad, la presencia de los miembros de los sectores medios y bajos de la sociedad local, que ingresaron con la sola condición de brindar algún

66 Bruno 1974.

67 Cruz 2002.

68 Los balances efectuados por Hermenegildo y Camilo González de Hoyos en el periodo comprendido entre 1818 y 1848, dan cuenta de que los ingresos de la cofradía no fueron suficientes para costear los gastos que demandaban sus actividades cultuales. Los sucesivos aportes de los mayordomos (prescindiendo aún, en ocasiones, del pago de las misas de renovación que, desde la fundación de la hermandad, debían celebrarse los primeros viernes de cada mes, y de las misas en auxilio de los cofrades vivos y difuntos) oscilaron entre los $\$ 3$ y los $\$ 400$, y se destinaron principalmente al pago de los servicios provistos por el clero, los músicos y cantores en la función del Corpus. ABHS. Libro de la cofradía Esclavitud del Santísimo Sacramento. 1774-1859.

69 ABHS. Libro de la cofradía Esclavitud del Santísimo Sacramento. 1774-1859.

70 El asiento individual de los cofrades puede vincularse a nuevas pautas de inscripción asociativa propias de la modernidad (Di Stefano 2002: 34). De hecho, esta modalidad será la que finalmente se impondrá como norma en las asociaciones locales propiamente decimonónicas. 
servicio y «servir en cuanto se ofrezca», sin pagar el estipendio de $\$ 4$ determinado constitucionalmente. La elite, por su parte, aunque reducida, continuó teniendo una significativa representación, asegurándose además el monopolio del ejercicio de la mayordomía. Y por último, porque el relativo equilibrio de género que la caracterizó a fines del periodo colonial dio paso a un notable predominio femenino. Si entre 1774 y 1810 la asociación se compuso de 186 mujeres y 200 hombres; entre 1811 y 1859, las primeras alcanzarán el número de 150, duplicando a los segundos.

En definitiva, en las postrimerías de la primera mitad del siglo XIX, la cofradía sacramental de la iglesia matriz de la ciudad había adquirido ya algunos de los rasgos que la definirán en el siguiente periodo; una asociación abierta con un acentuado perfil femenino.

La cofradía de Nuestra Señora del Carmen con asiento en el convento de Monte Carmelo presentó algunas características similares. Convergió en esta una feligresía constituida por miembros de los más diversos estratos sociales, y también allí, la elite local conservó importantes espacios de poder y decisión. ${ }^{71}$ Por otra parte, en líneas generales, la situación de la mujer fue similar en ambas asociaciones, hallándose formalmente imposibilitadas de acceder a los cargos de mayor relevancia, aunque con un protagonismo descollante en los preparativos de las jornadas festivas, la compostura y adorno de los templos, y la cotidiana gestión de los recursos. En ambas además, se evidencia la presencia de algunas de las mismas «mujeres decentes» que años más tarde constituirán la Sociedad de Beneficencia y las primeras conferencias vicentinas de la ciudad.

Los cambios mencionados repercutieron también en la economía de la hermandad sacramental. La disminución de sus miembros y el incremento de la modalidad de asiento sin el pago del estipendio estipulado redujo de forma considerable los recursos disponibles para la celebración de la festividad del Corpus y el cumplimiento de las misas por los cofrades vivos y difuntos. A diferencia del periodo precedente en el que los ingresos permitieron afrontar los gastos cotidianos con relativa holgura, durante buena parte de la primera mitad del siglo XIX estos se revelaron insuficientes, por lo que el sostenimiento de las actividades cofradieras dependió, casi de forma exclusiva, de los aportes particulares de la familia González de Hoyos. La situación era ya bastante crítica para el año de 1824 cuando, en función de los exiguos recursos de la hermandad, el Vicario Capitular ordenó que no se pagaran las misas de renovación (que deberían, en adelante, celebrarse voluntariamente por los religiosos de la iglesia matriz); que no se comprasen nuevos utensilios; y que se redujera el acostumbrado uso de la cera para el alumbramiento del octavario del Corpus. ${ }^{72}$ Sin embargo, tales disposiciones no tendrán efecto en la diezmada economía. Apenas algunos años más tarde, promediando la década de 1830, las actividades de la cofradía, antaño extendidas anualmente de principio a fin, se habían reducido únicamente a la recolección de limosnas y a una cada vez más austera (cuando no pobrísima)

\footnotetext{
71 AAS. Carpeta Asociaciones. Capítulos anuales de la cofradía de Nuestra Señora del Carmen del convento de Monte Carmelo. 1848-1855.

72 ABHS. Libro de la cofradía Esclavitud del Santísimo Sacramento.
} 1774-1859. celebración, en el mes de junio, de la festividad eucarística.

Fue también en el primer lustro del decenio de 1830 cuando las autoridades civiles procedieron a la enajenación de algunos de los bienes de la asociación, entre las medidas adoptadas a fin de afrontar las reparaciones de guerra que les impuso el caudillo federal Facundo Quiroga tras derrotar a las fuerzas unitarias locales. Aún cuando solo pudo afectarse a un raquítico patrimonio (principalmente utensilios de culto cuyo valor apenas alcanzó el importe de $\$ 40)$, la intervención significó un duro revés en el marco de la crisis general que la afectaba. ${ }^{73}$

Durante el transcurso de las décadas siguientes la situación económica de la cofradía no prosperó. Por el contrario, los males que la aquejaban, todavía a principios de 1860, parecían amenazarla de muerte, «hallándose completamente exhausta de recursos de un modo de tal que no podía satisfacer siquiera el valor de la cera que se preparaba para la función principal». ${ }^{74}$ Su estado decadente no era excepcional pues otras también acusaban algunos síntomas de relativa fragilidad, entre ellas la de Nuestra Señora del Carmen con asiento en la iglesia matriz que se hallaba al borde de su extinción, y la de San Benito de Palermo del convento seráfico desvalida por el escaso número de sus cofrades. ${ }^{75}$

Para comprender el paulatino proceso de deterioro de estas experiencias asociativas, resulta menester también considerar el impacto que tuvieron (o pudieron tener) diversas medidas que, adoptadas por los sucesivos gobiernos civiles en el transcurso de la primera mitad del siglo XIX, afectaron a los bienes de la Iglesia y sus corporaciones, y pretendieron efectuar algunas modificaciones en las prácticas religiosas de su feligresía. Sin ánimo de ser exhaustivos, mencionaremos tan solo algunas de ellas. La primera data del 3 de enero de 1815, a través de la cual el Director Supremo de las Provincias Unidas del Río de la Plata dispuso el ingreso en la Tesorería del Estado de "todas las sumas pertenecientes a fábrica de Iglesias y cofradías piadosas que se hallen existentes». ${ }^{76}$ La medida, que respondía a la necesidad de recursos que la guerra revolucionaria demandaba, bien pronto fue ejecutada, en el espacio local, por el gobernador Martín Miguel de Güemes que ya en el año de 1816 había afectado \$278 pertenecientes a la cofradía de San Benito. ${ }^{77}$ No obstante, la enajenación emprendida tuvo efectos limitados en lo que respecta a este tipo de asociaciones, pues por un lado, como ya mencionados en líneas anteriores, la situación de las mismas, en líneas generales, era económicamente delicada para aquel entonces; y por otro, porque no fue extensiva a todas ellas. La del Santísimo Sacramento, al menos en el decenio de 1810, no sufrió ningún tipo de intervención civil que afectara su patrimonio, como si sucedió en el de 1830. Cabe aclarar además que no se trató de una empresa llevada a cabo por funcionarios civiles adversarios a este

\footnotetext{
73 Ídem.

74 AAS. Comunicación del mayordomo y capellán de la cofradía, presbítero Federico Toledo, al obispo de la diócesis, Buenaventura Rizo Patrón. 1864.

75 AAS. Carpeta Asociaciones. Informe de cofradías de la ciudad. 1851.

7 ABHS. Fondo de Gobierno. Carpeta no 32 A. Febrero de 1815. 77 ABHS. Fondo de Gobierno. Carpeta no33. Octubre de 1816.
} 
tipo de experiencias asociativas, por el contrario, algunos de los que intervinieron en ella, como el ministro de Hacienda, Pedro Antonio Ceballos y Pintos, eran cofrades de algunas de estas hermandades. ${ }^{78}$

Otra fue la que en el año de 1831 autorizó al gobierno provincial «a vender y enajenar los bienes raíces y demás pertenecientes a obras pías de toda clase $"{ }^{79}$ a fin de paliar el crónico déficit de sus arcas fiscales. La ordenanza, aunque limitada en su aplicación y ceñida fundamentalmente sobre las capellanías existentes ${ }^{80}$ pudo afectar a las actividades cultuales promovidas por cofradías y hermandades religiosas sujetas a los beneficios de los réditos capellánicos, que a partir de entonces debieron ser satisfechos por una Tesorería estatal considerablemente debilitada.

Por último, debemos considerar aquellas disposiciones promocionadas desde el fuero civil con el objeto de reformar ciertas prácticas religiosas que, fomentadas por estas asociaciones, ya para aquel entonces se percibían nocivas y peligrosas. Así por ejemplo, en el año de 1850 el ejecutivo provincial, deseando "excitar el celo pastoral y patriótico» del provisor y vicario capitular de la diócesis, le sugería la disminución del número de "fiestas religiosas entre semana», pues estas, destinadas en su institución a ejercicios espirituales y piadosos, se habían desnaturalizado "sirviendo de fomento con el ocio a los vicios y desordenes, enemigos de la industria, de la sana moral, del progreso, de la civilización y de la misma Religión Santa». ${ }^{81}$

\section{COFRADÍAS RELIGIOSAS EN UN NUEVO ESCENARIO DECIMONÓ-} NICO, 1862-1880

Durante el transcurso de la segunda mitad del siglo XIX el tratamiento de la pobreza y la mendicidad, propició una nueva instancia de articulación entre autoridades civiles y eclesiásticas locales. Las elites dirigentes se valieron de los servicios del clero y de una particular transfiguración del principio de la caridad cristiana para regenerar moralmente a aquellos que podían amenazar la producción y reproducción del orden social. Para los pastores de la Iglesia este proyecto fue auspicioso en la medida en que les permitió perpetuar su injerencia en el campo de la beneficencia que ya para aquel entonces empezaba a conformarse como tal.

Amén de esta comunión de intereses, varios conflictos se suscitaron durante el periodo entre ambas partes, motivados principalmente, de acuerdo a la percepción de las autoridades civiles, por la desobediencia del clero respecto a sus deberes patrióticos y ciudadanos, y para la de estos últimos, por los excesos del poder temporal en el ejercicio de su derecho de patronato.

Fue este además un periodo en el que ambos, Estado e Iglesia, fueron definiendo paulatinamente sus respectivas esferas de acción y sus legítimas atribuciones, en un proceso de institucionalización que cristalizará ya en las postrimerías

78 ABHS. Libro de la cofradía Esclavitud del Santísimo Sacramento. 1774-1859.

79 ABHS. Fondo de Gobierno. Leyes y decretos. Sala de Representantes. 1830-1831. Decreto Enajenación de bienes raíces y obras pías. 1831.

80 Levaggi 1985.

81 AAS. Comunicación remitida por el gobernador de la provincia, Vicente Tamayo, al provisor y vicario capitular de la diócesis. 1850. del siglo XIX e inicios del $X X ;{ }^{82}$ periodo en el que también emergerá con fuerza un nuevo actor social propiamente decimonónico, el laicado, forjado por el espíritu de asedio que el nuevo obispo de la diócesis, Buenaventura Rizo Patrón, en correspondencia con los designios romanos, tan enérgicamente se encargó de difundir en el espacio local.

En el transcurso de la década de 1860 y 1870 el panorama de las cofradías y hermandades religiosas cambió respecto al de tan solo algunos años atrás, presentándose ahora mucho más auspicioso y prometedor. Los motivos de tal transformación pudieron ser diversos. Nos detendremos solo en explicar (tentativamente) a aquellos sobre los cuales las fuentes documentales nos brindan algunas pocas pruebas. En primer lugar, los mayores esfuerzos del clero local por mantener con vida a este tipo de experiencia asociativa sobre las que recaía el sostén del culto público. Ya en el año de 1862 el vicario general de la diócesis, Isidoro Fernández, encomendó la dirección de aquellas con asiento en la iglesia catedral de la ciudad a sus delegados eclesiásticos, al tiempo que emprendía en las localidades del interior de la provincia la fundación de otras nuevas. ${ }^{83}$ Algunas de estas medidas que ya antes habían sido ensayadas, ${ }^{84}$ se revelaron ahora más eficaces en parte, quizás, por la celosa gestión del nuevo pastor de la diócesis, Buenaventura Rizo Patrón. $\mathrm{Y}$ en segundo, por la emergencia de un vigoroso laicado, principalmente femenino, que asumió para con la Iglesia, sus agentes y asociaciones un férreo compromiso. En líneas generales, fueron las mismas mujeres de elite quienes conformaron las diversas cofradías decimonónicas y aquellas asociaciones orientadas a la labor benéfica, sosteniéndolas con sus aportes.

A pesar del renovado dinamismo que experimentaron las cofradías religiosas durante este periodo, principalmente la del Santísimo Sacramento como veremos a continuación, en líneas generales estas experiencias asociativas fueron perdiendo importancia relativa respecto de las sociedades benéficas, cada vez más numerosas y con mayores atribuciones sociales conforme avanzó la segunda mitad del siglo XIX.

\section{Cofradías y clericalización}

Como mencionamos en líneas anteriores, ya hacia finales del decenio de 1840, la dirección y administración de la cofradía Esclavitud del Santísimo Sacramento devino en una prerrogativa exclusiva de los agentes eclesiásticos, asumida de forma sucesiva por Gabriel Díaz (1848-1864), Federico Toledo (1864-1866) y Matías Linares (1866-1890) quienes concentraron en sus manos, de forma simultánea, los cargos de mayordomo y capellán de la asociación, ocupándose consecuentemente, de sus asuntos mundanos y espirituales. Dicho proceso supuso una plena sujeción de la herman-

82 Di Stefano 2011

83 AAS. Carpeta Iglesia Catedral. Informe del Vicario General, Isidoro Fernández. 1862.

84 Como mencionamos en líneas anteriores, los intentos de los agentes eclesiásticos por fundar nuevas cofradías y hermandades no prosperaron durante la década de 1850. Asimismo, la del Santísimo Sacramento hacía ya varios lustros atrás que se encontraba sujeta a la dirección de aquellos sin que pudieran revertir su crítica situación económica. 
dad a los designios del clero, máxime si se considera que ya para aquel entonces y hasta principios del siglo $\mathrm{XX}$, los oficios de menor relevancia (tesorero, secretario y celador), que debían garantizar la participación del laicado católico en sus cuadros directivos, no pudieron ser cubiertos por la ausencia de los hombres a los cuales se encontraban reservados. ${ }^{85}$ La dirección eclesiástica de la hermandad implicó también que sus recursos pecuniarios se confundieran cada vez más con los de la fábrica de la iglesia catedral empleándose, en diversas ocasiones y ya sin una instancia de intermediación laica, en el sostenimiento de esta última y sus servicios de culto. La circunscripción de la cofradía al ámbito eclesiástico se reforzó además por las normativas institucionales que la vincularon con el cabildo catedralicio local que en calidad de su patrono/capellán debió de celebrar sus funciones de coro y altar.

A partir de 1866 la recuperación de la hermandad, luego de varias décadas de privaciones e insuficiencias, fue evidente. Nuevamente se celebran de forma regular las misas en beneficio de los cofrades vivos y difuntos, y la función del Corpus recobra parte de su antiguo esplendor. Así lo atestiguan los sucesivos balances positivos que arrojan sus cuentas y las crónicas de los viajeros que, de paso por la ciudad, describían la solemnidad y adorno de la festividad eucarística;

En efecto, es el día del corpus (...) no entraré a describir el adorno tal vez churrigueresco de sus calles, me ocupare del conjunto, no sin hacer mención sin embargo de dos preciosísimos altares, que llamaron mi atención en la calle de la Victoria; uno formado con flores con un gusto exquisito, y el otro construido con paja de trigo, que es una obra de arte tanto por su esbelta sencillez como por la perfección de sus detalles. La carrera que debía seguir la procesión presentaba un golpe de vista sorprendente; las señoras convertidas en artistas adornaban los pequeños altares en los que debía reposar por breves instantes el pan eucarístico; tendiansen las alfombras en la calle; adornabase las fachas de los edificios; notándose en todo esto algo de santo recogimiento mezclado con un tinte de inefable alegría que me decía de una manera elocuente; he ahí la fe de un pueblo que conserva la fe de sus mayores, he ahí una sociedad que cree y espera. ${ }^{86}$

La cita transcripta nos permite además visualizar la actualización de una piedad emotiva que debía expresarse en los adminículos exteriores, visibles y materiales del culto público ${ }^{87}$ para constituirse en la manifestación de fe de un laicado militante inmerso en un contexto que, a los ojos de los pastores de la Iglesia, se percibía adverso y amenazante.

En líneas generales, las actividades cultuales de la recuperada cofradía no difirieron demasiado de aquellas desplegadas hacia fines del periodo colonial. Sus recursos se

85 AAS. Carpeta Asociaciones. Libro de la cofradía del Santísimo Sacramento. 1866-1920.

${ }^{86}$ ABHS. Periódico La Reforma. 02-06-1877. El día del Corpus en Salta. Pp. 2.

87 Ya en el año de 1864 Lorenzo Aznares, gobernador delegado eclesiástico de la diócesis, le solicitaba al clero y a los fieles de la ciudad un sincero homenaje a su Divina Majestad en la función del Corpus Christi, «no sólo con las oblaciones de su corazón sino también con las demostraciones exteriores de ornato en las calles». AAS. Carpeta Cabildo Eclesiástico. 1864. destinaron principalmente, igual que antaño, al pago de los servicios provistos por los religiosos (misas y sermones) y al de los músicos, y al costeo de la iluminación del novenario y octavario del Corpus. La principal novedad del periodo, no obstante, fue el compromiso que la asociación asumió para con el culto al Sagrado Corazón de Jesús en correspondencia con la modificaciones devocionales inscriptas en el proceso de romanización que por aquel entonces llevaba adelante la Iglesia católica. ${ }^{88}$ Durante los primeros días del mes junio empezaban ya los preparativos. Algunas mujeres, principalmente las de la elite, oficiaban de alumbrantes de la advocación contribuyendo con una cuantiosa limosna, mientras la hermandad se encargaba de costear la celebración de las misas cantadas y los sermones a fin de reparar los agravios de los infieles indiferentes. ${ }^{89}$

Para de la década de 1870 la dirección de la cofradía sacramental era un asunto exclusivamente eclesiástico, correspondiente en primera instancia a su mayordomo capellán y, a través de este, al obispo de la diócesis. En sus libros ya no registraba ninguna intervención del poder civil que pudiera suponer algún tipo de jurisdicción compartida; atrás habían quedado las obligaciones que este había asumido en un lejano pasado colonial cuando, en calidad de patrono, debía costear el alumbrado del octavario del Corpus. La presencia de las autoridades civiles solo fue visible en la pública procesión eucarística a la que asistían en calidad de fieles acompañados por la banda de música y por las tropas de diversos regimientos locales. ${ }^{90}$

Esta redefinición jurisdiccional operada en la segunda mitad del siglo XIX también comprendió a otras cofradías y hermandades locales, entre ellas a la de Nuestra Señora del Rosario y la de Benditas Ánimas, administradas igualmente por los mismos mayordomos-capellanes que la del Santísimo Sacramento.

\section{Cofradías y mujeres}

Hacia fines de la década de 1860 la feminización de la hermandad sacramental, iniciada en el periodo precedente, se había consumado. La presencia masculina, para aquel entonces, era ya prácticamente nula llegando al extremo de no poderse cubrir los pocos cargos administrativos que la asociación reservaba a los hombres. ${ }^{91}$ Este fenómeno, también evidente en la cofradía de Nuestra Señora del Rosario, ${ }^{92}$ se inscribió en un proceso de redefinición decimonónica de las virtudes y funciones sociales de género, por el que el ejercicio de la beneficencia y el culto público se concibieron como prerrogativas femeninas, principalmente de las mujeres pertenecientes a la elite. En los escritos literarios de la época, en las comunicaciones de las autoridades civiles y en las reflexiones de los pastores de la iglesia, el arquetipo de mujer ideal se definió por sus atributos angelicales,

88 Di Stefano 2009: 293.

89 AAS. Carpeta Asociaciones. Libro de la cofradía del Santísimo Sacramento. 1866-1920.

90 ABHS. Periódico La Reforma. 9-07-1877. La función del corpus en San Francisco. Pp. 2.

91 AAS. Carpeta Iglesia Catedral. Visita pastoral, obispo de la diócesis, Rizo Patrón. 1872.

92 AAS. Carpeta Asociaciones. Libro de la Cofradía de Ntra. Señora del Rosario. 1880-1899. 
funcionales a la empresa de moralización emprendida por los sectores dirigentes en connivencia con el clero. Sensibilidad, abnegación, caridad y religiosidad fueron las principales virtudes legitimantes de la intervención femenina en los diversos establecimientos sociales que durante el periodo se fundaron (hospitales, asilos y casas correccionales) y del rol protagónico que adquirieron las mujeres, como parte del laicado militante, en la defensa de la religión y sus funciones sociales

En esta tierra feliz que el ojo de dios acaricia siempre, la mujer nace hermosa como las hijas del Cáucaso, cándida e inocente como la pastora bíblica, graciosa como la proverbial española, espiritual como la francesa, sería como la inglesa, sensata y casera como la norteamericana. Entre sus cualidades sobresale el predominio del sentimiento religioso, que moraliza, que expande la imaginación, que engendra virtudes dulces y apacibles, que viriliza la inteligencia que da movimiento al cuerpo social, que hasta fomenta el comercio (...). La mujer salteña trabaja por el bien público más que el hombre, por el bien público entiendo el mejoramiento de las clases sociales, la educación, la protección del desvalido, la salubridad pública y el ornato. Sí, porque la mujer es más caritativa que el hombre, mientras el hombre apunta lo que gana en plata, ella apunta lo que gana en sentimiento, en virtud (...) en el haber del libro del hombre esta su nombre, en el de la mujer la humanidad (...). ${ }^{93}$

La cita transcripta resulta bastante ilustrativa de la producción y reproducción de ciertas imágenes modélicas que se sancionaban desde una incipiente esfera pública, y de las pretensiones de subordinar la «naturaleza femenina» a un fin especifico; la utilidad pública. De acuerdo a la percepción de una pequeña elite intelectual, conformada, en líneas generales, por miembros de la naciente burocracia estatal/provincial, la religiosidad y la caridad de las mujeres debía "civilizarse», es decir mantenerse apartada del fanatismo y la intolerancia para sujetarse principalmente a sus consabidas obligaciones cultuales y a los lineamientos de un específico programa de gobierno orientado a la regeneración moral de los pobres y desvalidos. Por su parte, para las autoridades eclesiásticas locales, la exacerbación de la "ferviente devoción que residía en el corazón de la mujer ${ }^{94}$ constituyó el fundamento de una cruzada destinada a contrarrestar los ultrajes dirigidos contra la Iglesia y combatir el indiferentismo religioso que aquejaba a los hombres.

La redefinición decimonónica que sancionó esferas legítimas de actuación en función de los atributos de género se tradujo también, naturalmente, en el plano asociativo local, y fue precisamente en el periodo comprendido entre 1860 y 1880 cuando por vez primera se expresó allí con mayor nitidez. Quienes conformaron la cofradía Esclavitud del Santísimo Sacramento durante la segunda mitad del siglo XIX fueron también aquellas mujeres que nutrieron las filas de otras hermandades y que, de forma simultánea,

93 ABHS. Periódico La Reforma. «La mujer salteña y su influencia en el progreso social de la provincia». Discurso pronunciado por Pablo Zubieta en el acto de inauguración de la Asociación El Ateneo Salteño. 12-09-1877, p. 3.

94 AAS. Carpeta Asociaciones. Comunicación de Gregorio Romero a las mujeres del Apostolado de la Oración. 1884. integraron las más diversas asociaciones benéficas locales. La múltiple adscripción asociativa fue un rasgo común en el periodo, destacándose algunas trayectorias realmente excepcionales, como la de Rosa Barrenechea de Ojeda, matrona local que además de pertenecer a las referidas hermandades fue una de las damas decentes que restableció la Sociedad de Beneficencia en el año de 1864, promovió el establecimiento de las primeras conferencias vicentinas en la década de 1870 y fundó, en 1879, la Asociación Jubileo Pio IX.

Pero las hermandades religiosas, como mencionamos anteriormente, no fueron espacios caracterizados por su elitismo. Por el contrario, el proceso de popularización que experimentó la cofradía del Santísimo Sacramento a partir de 1830, se pronunció en las décadas siguientes, de forma tal que, para 1860, las mujeres de la elite que la componían, constituían ya una minoría, fenómeno también observado en otras hermandades como la de Nuestra Señora del Carmen con asiento en el convento de Monte Carmelo y la de Nuestra Señora del Rosario en la iglesia catedral. Esta heterogénea composición nos permite visualizar a tales asociaciones como espacios de cohesión e integración social en los que el conjunto de cofradas se hallaban hermanadas por el compromiso público con una advocación específica y por una red de solidaridad espiritual que sujetaba la salvación de las almas de cada una de ellas al esfuerzo conjunto de todas las partes involucradas. Esta comunión de intereses no ocultaba, sin embargo, las grandes distancias sociales que mediaban entre las mujeres devotas, pues aun cuando los más importantes cargos de gobierno se reservaran a los agentes eclesiásticos, las damas decentes desempeñaron un rol crucial en el sostenimiento del culto eucarístico, distinguiéndose de las demás por sus cuantiosas limosnas que les permitían constituirse en las alumbrantes encargadas del costear las velas de las públicas jornadas festivas.

\section{CONSIDERACIONES FINALES}

La reconstrucción de la historia de la cofradía del Santísimo Sacramento, desde fines del siglo XVIII a fines del XIX nos ha permitido abordar una parte de la trayectoria particular de la secularización en la ciudad de Salta, es decir del proceso de recomposición, adaptación y relocalización de la religión en el tránsito de un régimen de cristiandad a una modernidad religiosa..$^{95}$

Jurisdiccionalmente, luego de un periodo de tutela compartida entre autoridades civiles y eclesiásticas, coloniales y republicanas, la asociación se sujetó de forma exclusiva a la órbita de los curas rectores de la iglesia catedral y su cabildo, y a través de estos, a la del obispo diocesano. Este pasaje se inscribió en el proceso de institucionalización que la Iglesia argentina emprendió avanzada la segunda mitad del siglo XIX y que, en el campo asociativo local, se tradujo en un reforzamiento de las experiencias asociativas consagradas al culto sagrado que, más que nunca antes, debió constituir un verdadero testimonio de fe ante la indiferencia de algunos actores sociales (principalmente masculinos) y las desavenencias producidas en la reformulación decimonóni-

\footnotetext{
95 Di Stefano 2011
} 
ca de las relaciones entre agentes estatales y eclesiásticos.

Desde una perspectiva de género, la feminización de sus filas reflejó un proceso general de feminización de la religión evidente no solo en otras hermandades religiosas sino también en las sociedades benéficas orientadas a brindar auxilio espiritual y corporal a los pobres y desvalidos, y en los apostolados y terceras órdenes que emergerán en el espacio local a partir de la década de 1880 . El distanciamiento de los hombres de la elite respecto a estas asociaciones señala claramente las modificaciones operadas en el ámbito de las prácticas religiosas aunque no «necesariamente la pérdida de sus creencias religiosas y de sus referentes sagrados $",{ }^{96}$ pues fueron ellos mismos quienes, en parte, también las promovieron, las sostuvieron con sus aportes y se involucraron en la gestión de sus proyectos.

Socialmente la cofradía sacramental dejó de ser la expresión asociativa (aunque no exclusiva) de un grupo selecto para nutrirse de una feligresía heterogénea. Ello, sin embargo, no supuso la homogenización de sus miembros, pues nuevos y viejos mecanismos de diferenciación social se activaron en su seno. En líneas generales fueron las mujeres de la elite quienes siempre se encargaron de la gestión cotidiana de los recursos de la hermandad y de la coordinación de los preparativos del culto, y quienes, a partir de la década de 1870 , se distinguieron del resto por las cuantiosas limosnas que, en calidad de "alumbrantes», aportaron para el alumbrado de la función principal.

A pesar de los cambios mencionados, algunos elementos se mantuvieron incólumes. El culto fue siempre su principal objetivo junto a la provisión de gracias e indulgencias para el auxilio de las almas de los cofrades vivos y difuntos. En esta permanencia se observan, no obstante, algunas modificaciones como la incorporación en su calendario ritual de la festividad del Sagrado Corazón de Jesús que coincidía con la celebración del novenario del Corpus.

El conjunto de medidas laicas implementadas por el gobierno nacional en el primer lustro de la década de 1880 inaugurará una nueva coyuntura conflictiva entre agentes estatales y eclesiásticos, y que en el escenario local propiciará el enfrentamiento entre el gobernador Juan Solá y el obispo de la diócesis, fray Buenaventura Rizo Patrón. Para entonces, la cofradía, ya recuperada, aunará esfuerzos con las demás asociaciones religiosas/benéficas a fin de promover la fundación de diversos establecimientos educativos de carácter confesional, sostener económicamente las publicaciones católicas e invadir las calles de la ciudad con múltiples manifestaciones de fe.

\section{BibLIOgRAFíA}

Arias de Saavedra, I. y De Luis, M. F. 1997. "Debate político y control estatal de las cofradías españolas en el siglo XVIII». Bulletin Hispanique 99 (2): 423-435. http://www.persee.fr/doc/ hispa_0007-4640_1997_num_99_2_4948

Barral, M. a E. 1998. Iglesia, poder y parentesco en el mundo rural colonial. La cofradía de Benditas Ánimas del Purgatorio, Pilar: 1774. Luján: Universidad de Luján. Colección Cuadernos de Trabajo 10.

Bruno, C. 1974. Historia de la Iglesia en la Argentina. Vol. 9. Buenos Aires: Don Bosco.

\footnotetext{
96 Di Stefano 2008: 162.
}

Garavaglia, J. C. 2002. «Del Corpus a los toros: fiesta, ritual y sociedad en el río de la plata colonial». Anuario IEHS 17: 391-419.

Caretta, G. 1999. «Con el poder de las palabras», en E. S. Mata (comp.), Persistencias y cambios: Salta y el noroeste argentino. 1779-1840. Rosario: Prohistoria \& Manuel Suárez.

Caretta, G. y Marchionni, M. 2000. «Entre la feligresía y la ciudadanía. Una cuestión de poder en Salta a principios del siglo XIX». Andes. Antropología e Historia 11: 115-164.

Carbajal López, D. 2012a. "Las reformas de las cofradías novohispanas en el Consejo de Indias, 1767-1820». Revista Complutense de Historia de América 38: 79-101. https://doi.org/10.5209/rev_ rcha.2012.v38.40235

Carbajal López, D. 2012b. "Las reformas de la cofradías en el siglo XVIII: Nueva España y Sevilla en comparación». Estudios de historia Novohispana 48: 3-33. https://doi.org/10.1016/ s1870-9060(13)72430-0

Cruz, E. N. 2002. "Autoridades socio-religiosas en el antiguo régimen. Los mayordomos de cofradías en el Jujuy colonial». Cuadernos del Sur 30-31: 35-56.

Cruz, E. N. 2009. La política social en el antiguo régimen, cofradías, hospitales, profesión médica, declaraciones de pobreza y motes píos en el Jujuy colonial. Jujuy: Ed. Purmamarka.

Cruz, E. N. 2011. Historia del Jujuy colonial. Salta: Purmamarka.

Cruz, E. N. 2013. "Diferencias étnicas y de género en las cofradías y fiestas religiosas (siglo XVIII, Jujuy en el Río de la Plata», en E. N. Cruz, J. P. Ferreiro y D. J. Santamaría (eds.), Mi propiedad privada. Relaciones de poder y de género en el periodo colonial (Jujuy, siglos XVII al XIX): 39-65. Salta: Purmamarka ediciones.

Di Stefano, R. 2002. "Orígenes del movimiento asociativo: de las cofradías coloniales al auge mutualista», en E. Luna y É. Cecconi (coords.), De las cofradías a las organizaciones de la sociedad civil. Historia de la iniciativa asociativa en la Argentina, 1776-1990: 22-97. Buenos Aires: Gadis.

Di Stefano, R. 2008. «Disidencia religiosa y secularización en el siglo XIX Iberoamericano: cuestiones conceptuales y metodológicas». Projeto Historia, Sao Pablo 37: 157-178. http://revistas.pucsp.br/ index.php/revph/article/viewFile/3050/1963

Di Stefano, R. 2009. Historia de la Iglesia Argentina. Desde la conquista hasta fines del siglo XX. Buenos Aires: Sudamericana.

Di Stefano, R. 2011. «Por una historia de la secularización y la laicidad en la Argentina». Quinto Sol 15 (1): 1-30.

Estruch, D. 2009. «Fundar, gobernar y rezar. Una aproximación a los vínculos entre sociedad, política y religión en el Jujuy colonial (1656-1776)». Runa XXX (1): 61-78.

Fogelman, P. 2000. "Una cofradía mariana urbana y otra rural en Buenos Aires a fines del período colonia». Andes, Antropología e Historia 11: 179-207.

Fogelman, P. 2004. "Una economía espiritual de la salvación. Culpabilidad, purgatorio y acumulación de indulgencias en la era colonial». Andes, Antropología e Historia 15: 55-86.

Giménez García, J. A. 2005. «Las cofradías almerienses entre el siglo de las luces y la desamortización: 1796-1854». Chronica Nova. Revista de historia moderna de la Universidad de Granada 31: 327-348. http://revistaseug.ugr.es/index.php/cnova/article/ view/1811/1994

González Fasani, M. 2006. «¿Qué entendemos por cofradía colonial?: Una aproximación para el marco teórico de su estudio», en H. R. Zapico (coord.), De prácticas, comportamientos y formas de representación social en Buenos Aires (Siglo XVII-XIX): 225-259. Bahía Blanca: Publicaciones de la Universidad Nacional del Sur.

González García, Y. 1984. «Desintegración de bienes de cofradías y de fondos píos en Costa Rica, 1805-1845». Mesoamérica 5: 279-303

Lempérière, A. 2008. "Orden corporativo y orden social. La reforma de las cofradías en la ciudad de México, siglos XVIII-XIX». Historia y Sociedad 14: 9-21. http://www.bdigital.unal.edu. co/25900/1/23397-81459-1-PB.pdf.

Levaggi, A. 1985. «La redención de capellanías en Salta en el periodo de 1831-1854». Boletín del Instituto de San Felipe y Santiago de Estudios Históricos 38: 153-172. 
Marchionni, M. 1999. «Una elite consolidada. El cabildo de Salta en tiempo de cambios», en S. Mata de López (comp.), Persistencias y cambios. Salta y el Noroeste argentino. 1770-1840: 177-217. Rosario: Prohistoria.

Marchionni, M. 2000. «Acceso y permanencia de las elites en el poder político local. El cabildo de Salta a fines del periodo colonial». Cuadernos FHYCS-UNJu 13: 281-304

Martínez de Sánchez, A. M.a 2006. Cofradías y obras pías en Córdoba del Tucumán, Córdoba. Córdoba: Editorial de la Universidad Católica de Córdoba.

Martínez Gil, F. y Rodríguez González, A. 2002. «Del barroco a la Ilustración en una fiesta del Antiguo Régimen: el Corpus Christi». Cuadernos de Historia Moderna Anejos I: De mentalidades y formas culturales en la Edad Moderna: 151-175. http://revistas.ucm. es/index.php/CHMO/article/view/CHMO0202220151A/22664 [Fecha de consulta: 4 de diciembre de 2016].

Muñoz, G. y López, M. L. 2002. «Debate y reacción a las reformas ilustradas: maniobras legales de las cofradías a finales del siglo XVIII». Chronica Nova. Revista de historia moderna de la Universidad de Granada 29: 179-216. http://revistaseug.ugr.es/index.php/cnova/ article/view/2001/2165
Núñez y Ruiz-Díaz, S. R. 2015. "La Archicofradía del Santísimo Sacramento de la Catedral de Buenos Aires. Siglos XVI al XVIII». Revista Cruz del Sur V (14): 301-356

Palomo Infante, M.a D. 2004. «Tiempos de secularización: iglesia y cofradías en Chiapas a partir de 1856». Mesoamérica 46: 153-172.

Ramos Alfonso, R. 2006. "La fiesta del corpus en la Marchena barroca. Escenografía y elementos simbólicos». Revista de Marchena: 113131. http://www.bibliotecaspublicas.es/marchena/imagenes/ XII_5_Ramos_corpus.pdf [Fecha de consulta: 29 de diciembre de 2016]

Rodríguez de Gracia, H. 2004. «El Corpus de Toledo. Una fiesta religiosa y profana en los siglos XVI y XVII». Zainak 26: 385-410. http:// www.euskomedia.org/PDFAnlt/zainak/26/26385410.pdf [Fecha de consulta: 3 de diciembre de 2016]

Serrano, S. 2003. «Espacio público y espacio religioso en Chile republicano». Teología y Vida, XLIV: 346-355. http://www.scielo.cl/scielo. php?script=sci_arttext\&pid=S0049-34492003000200015

Timón, S. V. 2011. «La fiesta del Corpus Christi en el reino de Castilla durante la Edad Moderna». Ab Initio 3: 45-57. http://www.ab-initio.es/wp-content/uploads/2013/03/0303-CORPUS.pdf [Fecha de consulta: 2 de diciembre de 2016] 